\title{
Modelling the competition for forest resources: The case of Sweden
}

\author{
Anna Olsson, Robert Lundmark \\ Economics Unit, Luleå University of Technology, Luleå, Sweden \\ Email address: \\ Anna.Olsson@1tu.se (A. Olsson), Robert.Lundmark@1tu.se (R. Lundmark)
}

To cite this article:

Anna Olsson, Robert Lundmark. Modelling the Competition for Forest Resources: The Case of Sweden. Journal of Energy and Natural Resources. Vol. 3, No. 2, 2014, pp. 11-19. doi: 10.11648/j.jenr.20140302.11

\begin{abstract}
Past decades increasing shares of forest resources have been diverted from the forest sector to the energy sector. The increasing utilization of forest fuel is, to a large extent, caused by economic policies introduced to reduce the emission of greenhouse gases. Since the energy sector is believed to continue to increase its use of forest fuel in the energy production in Sweden, it is of interest to investigate the effects of this. The purpose of this study is to analyses the extent and degree of forest resources competition in the presence of climate policy by accounting for the inter-linkages of forest resources utilization between the energy sector and the forest industries. A partial equilibrium model was thus constructed and applied to the Swedish forest sector and energy sector. A baseline scenario is calibrated using the GAMS software. Four scenarios with alternative development paths are then simulated and compared to the baseline scenario. The results indicate that the impacts on the procurement competition between the forest sector and the energy sector are relatively moderate also in situations of expanding production in the forest industries. An increase in the competition between industries in the energy sector can however be observed.
\end{abstract}

Keywords: Partial Equilibrium Model, Forestry, Forest Industries, Energy Sector, Bioenergy, Forest Fuel

\section{Introduction}

This study focuses on procurement and market issues of forest products used by the energy sector and forest industries. The specific purpose is to analyze the extent and degree of the competition for forest products in the presence of climate and energy policies. This is done by developing a partial equilibrium model capturing the forest and the energy industries and the product flows to and between them. The model is applied on Sweden, which is a good case-study since it has both a large forest industry and a significant utilization of forest products in the energy sector.

Historically, the bulk of forest products have been used by the forest industries. Lately however, increasing shares are diverted to the energy sector. The increasing utilization by the energy sector is, to a large extent, caused by changes in the relative price between biofuels and alternative fuels. In turn, the changing relative prices are partly a consequence of the economic instruments and policies introduced to e.g., reduce the emission of greenhouse gases.

In countries where forests already are highly utilized, such instruments might result in an increase in the procurement competition between the forest industries and the energy sector (e.g., Hammarlund et al., 2010; Lundmark and Söderholm, 2004; Brännlund et al., 2010).In this context, it is important to note that an intensified competition, as a result of market interventions, is not a problem in itself from an economic perspective if the policies are implemented to correct for market failures. For example, if a carbon tax, which changes the relative price between fossil fuels and biofuels, is reflecting the social cost of the negative external effect.

Forest products are normally allocated on the basis of users' willingness to pay. Economic policies can change the willingness to pay for specific sectors both positively and negatively depending on the specific policy implemented. For example, a policy promoting the use of bioenergy will increase the energy sector's willingness to pay for forest products. Moreover, from an international perspective, national policies promoting the use of bioenergy can affect the competition of forest products between countries assuming that there are differences in the national policies (Brännlund et al, 2010; Hammarlund et al, 2010).

It has been estimated that the emission of greenhouse gases needs to be reduced by approximately 85 percent until 2050 to achieve the 2-degree target (Åkerman et al., 
2007). This is a central assumption in the forthcoming analysis. To achieve the emission target, substantial technological efficiency improvements have to be realized as well as changes in the current trends of both production and consumption of energy. From a production perspective it is important to stimulate the development of silvicultural - and agricultural - practices. An increasing supply of forest fuels can offset an increasing demand without causing price changes. But it is more likely that the increases in supply will not keep up with the increases in demand, causing price changes and an intensified competition.

\section{Modelling the Swedish Forest Sector}

The model is designed as an analytical tool for assessing the consequences of external changes. It has explicitly been designed to analyze how policies aimed to reduce emission of greenhouse gases will affect the forestry, forest industries and the energy sector.

\subsection{Model Overview and Assumptions}

The model is designed as a static partial equilibrium model for a closed economy. Equilibrium models have been used to analyze changes in market conditions for the forest sectors (e.g., Buongiorno et al., 2003; Lundmark, 2006). Input demand and supply functions as well as production technologies are defined for each industry under the assumption of profit maximizing behavior (Kallio et al., 2004).Assuming constant returns to scale, a CES production function for the $n$-factor case in the standard coefficient form is specified as:

$$
y_{i}^{f}=\gamma_{i}\left[\sum_{j} \alpha_{i}^{j}\left(x_{i}^{j}\right)^{\rho_{i}}\right]^{1 / \rho_{i}}
$$

Where $y_{i}^{f}$ is output $f$ of industry $i, \gamma_{i}$ is a scale parameter, $\alpha_{i}^{j}$ is a distribution parameter and $x_{i}^{j}$ is the demand of industry $I$ for input $j$, and $\rho_{i}=1 /\left(1-\sigma_{i}\right)$ where $\sigma_{i}$ is the elasticity of substitution (Varian, 1992). A list of all notations used in the model can be found in the Appendix. The production function is assumed to be weakly separable between forest products and other production factors, e.g., labor and capital (Varian, 1992).

The conditional input demand is derived by maximizing profits (or equivalently minimizing the cost for each level of output) and is expressed as:

$x_{i}^{j}=\left(\alpha_{i}^{j}\right)^{\sigma_{i}}\left(w^{j}\right)^{-\sigma_{i}} \gamma_{i}^{-1}\left[\sum_{j=1}^{n}\left(\alpha_{i}^{j}\right)^{\sigma_{i}}\left(w^{j}\right)^{\left(1-\sigma_{i}\right)}\right]^{\sigma_{i} /\left(1-\sigma_{i}\right)} y_{i}^{f}$

where $w^{j}$ is the price of input $j$. The inverse supply of forest resources is written as:

$$
w^{j}=\beta^{j}+\delta^{j}\left(\frac{x_{i}^{j}}{k^{j}}\right)^{1 / \phi^{j}}
$$

where $\beta^{j}$ is an exogenous cost component in forest product prices that is independent of harvesting levels, $\delta^{j}$ is a shift parameter accounting for factors other than price affecting the supply, $k^{j}$ is a capacity restriction, and the $\phi^{j}$ is the supply elasticity of input $j$.

The profit function $(\pi)$ is specified as:

$$
\pi_{i}=\sum p^{f} y_{i}^{f}-\sum w^{j} x_{i}^{j}
$$

The objective of the model is to maximize the sum of the individual sector's profit defined as:

$$
\pi_{T O T}=\sum \pi_{i}
$$

The sectors included are the forestry $(F)$,sawmill industry $(S)$, pulp and paper industry $(P)$ and the heating industry $(H)$. In total six forest products are included. The forestry sector supply roundwood $(R W)$ and logging residues $(L G)$. The production of roundwood is roughly equally divided between pulpwood and timber. Pulpwood is used by the pulp and paper industry and timber is used by the sawmill industry. Depending on its price, pulpwood can be used by the energy sector. The extraction of harvesting residues is conditional on a harvesting operation and is considered a by-product of the harvesting operation. Harvesting residues is not used by the forest industries, thus no immediate competition for it exists. It has been estimated that the extraction of logging residues could potentially increase before the competition between the forest industries and energy sector intensified (Swedish Forest Agency, 2009; Lundmark and Söderholm, 2004). The sawmill industry is producing sawdust and woodchips as a by-products $(B Y)$ from their main production of sawn wood products. The energy sector's choice between byproducts and logging residues is determined by the relative price. Since sawdust and woodchips are by-products, the supplied volume will not respond to changes in the price level. Only an increase in the production of sawn wood products will affect the supply of the by-products. The byproducts are mainly used by the pulp and paper industry, but are also relevant for the energy sector. The endogenous flow of forest products and the connection between the sectors are illustrated in Figure 1.

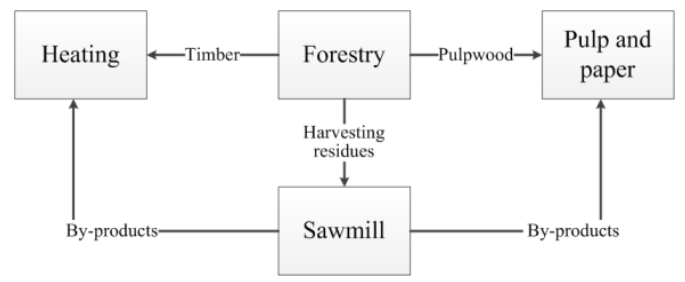

Figure 1. Actors and flows of forest resources in Sweden 


\subsection{Empirical Specification of the Forestry}

The specification of the forestry sector mainly follows the specification in Kallio et al. (2004). The inverse supply function of roundwood is specified as:

$$
w^{R W}=\beta^{R W}+\delta^{R W}\left(\frac{y_{F}^{R W}}{k^{R W}}\right)^{1 / \phi^{R W}}
$$

where $w^{R W}$ is the price of roundwood and $y_{F}^{R W}$ is the harvesting level of roundwood. $\beta^{R W}$ is an exogenous cost component of the roundwood price that is independent of harvesting levels (following Kallio et al. (2004) it is set at zero), $\delta^{R W}$ is a shift parameter accounting for factors other than price affecting the supply, $k^{R W}$ is a capacity restriction, and the $\phi^{R W}$ is the supply elasticity of roundwood. The baseline values of $w^{R W}, y_{F}^{R W}, \beta^{R W}$, along with the $k^{R W}$ and $\phi^{R W}$, is substituted into equation (4) in order to calibrate the value of $\delta^{R W}$. In order to ensure a sustainable forestry a restriction on the harvesting level of roundwood is applied.

$$
y_{F}^{R W}<\psi_{\text {FGROWTH }}
$$

The restriction requires the harvesting level of roundwood to be less than the annual growth rate of the forest $\left(\psi_{\text {FGROWTH }}\right)$. The inverse supply of logging residues is specified as:

$$
w^{L G}=\beta^{L G}+\delta^{L G}\left(\frac{y_{F}^{L G}}{k^{L G}}\right)^{1 / \phi^{L G}}
$$

Where $w^{L G}$ is the price of logging residues and $y_{F}^{L G}$ is the output level of logging residues from the forestry. $\beta^{L G}$ is an exogenous cost component in logging residue price that is independent of output level (following Kallio et al. (2004) it is set at zero), $\delta^{L G}$ is a shift parameter accounting for factors other than price affecting the supply, $k^{L G}$ is a capacity restriction, and the $\phi^{L G}$ is the supply elasticity of logging residues. The baseline values of $w^{L G}, y_{F}^{L G}, \beta^{L G}$, along with the $k^{L G}$ and $\phi^{L G}$, is substituted into equation (8) in order to calibrate the value of $\delta^{L G}$. The output level of logging residues, $y_{F}^{L G}$, is assumed not to exceed a fixed proportion $\left(\mu_{L G}\right)$ and is consequently conditional on the actual level harvested roundwood.

$$
y_{F}^{L G} \leq \mu^{L G} y_{F}^{R W}
$$

The value of $\mu^{L G}$ is calibrated by substituting the baseline values of $y_{F}^{L G}$ and $y_{F}^{R W}$ into equation (9). Following this the forestry's profit function is specified as:

$$
\pi_{F}=\left(p^{R W} y_{F}^{R W}+p^{L G} y_{F}^{L G}\right)-\tau_{F C O S T} x_{F}^{R W}
$$

The forestry's costs are assumed to be represented by $\tau_{F C O S T}$, which is the annual logging cost per cubic meter harvested roundwood.

\subsection{Empirical Specification of the Sawmill Industry}

The sawmill industry produces sawn wood products, sawdust and woodchips using roundwood as a single input. Thus, no production function is specified. The production of sawn wood products is assumed to be exogenously fixed. The inverse supply of by-products is specified as:

$$
w^{B Y}=\beta^{B Y}+\delta^{B Y}\left(\frac{y_{S}^{B Y}}{k^{B Y}}\right)^{1 / \phi^{B Y}}
$$

Where $w^{B Y}$ is the roundwood price and $y_{S}^{B Y}$ is the output level. $\beta^{B Y}$ is an exogenous cost component in the by-product price that is independent of output level, $\delta^{B Y}$ is a shift parameter accounting for factors other than price affecting the output, $k^{B Y}$ is a capacity restriction, and the $\phi^{B Y}$ is the supply elasticity of by-products. The baseline values of $w^{B Y}, y_{S}^{B Y}, \beta^{B Y}$, along with the $k^{B Y}$ and $\phi^{B Y}$, is substituted into equation (11) in order to calibrate the value of $\delta^{B Y}$.

The output level of by-products is proportional to sawmills' demand of roundwood. That is, the output level of by-products cannot exceed a fixed proportion $\left(\mu_{B Y}\right)$ of the actual quantity of roundwood used by sawmills.

$$
y_{S}^{B Y} \leq \mu^{B Y} x_{S}^{R W}
$$

The value of $\mu^{B Y}$ is calibrated by substituting the baseline values of $y_{S}^{B Y}$ and $x_{S}^{R W}$ into equation (12).

\subsection{Empirical Specification of the Pulp and Paper Industry}

The pulp and paper industry is assumed to use roundwood and by-products in their production. The CES production function is specified as:

$$
y_{P}^{P P}=\gamma_{P}\left[\alpha_{P}^{R W}\left(x_{P}^{R W}\right)^{-\rho_{P}}+\alpha_{P}^{B Y}\left(x_{P}^{B Y}\right)^{-\rho_{P}}\right]^{-1 / \rho_{P}}
$$

where $y_{P}^{P P}$ is the pulp and paper industry's output level of pulp, $x_{P}^{R W}$ and $x_{P}^{B Y}$ are the demanded input quantities of roundwood and by-products. $\gamma_{P}$ is a scale parameter for the 
pulp and paper industry, $\alpha_{P}^{R W}$ and $\alpha_{P}^{B Y}$ (where $\left.\alpha_{P}^{B Y}=\left(1-\alpha_{P}^{R W}\right)\right)$ are distribution parameters for roundwood and by-products respectively. These are calibrated using benchmark values. $\rho_{P}$ is the pulp and paper industry's specific $\rho$-value based on the elasticity of substitution $\left(\sigma_{P}\right)$ between the inputs. The pulp and paper industry's associated input demand functions of roundwood and byproducts are specified as:

$$
x_{P}^{R W}=\left(\alpha_{P}^{R W}\right)^{\sigma_{P}}\left(w^{R W}\right)^{-\sigma_{P}} \gamma_{P}^{-1}\left[\left(\alpha_{P}^{R W}\right)^{\sigma_{P}}\left(w^{R W}\right)^{\rho_{P} \sigma_{P}}+\left(\alpha_{P}^{B Y}\right)^{\sigma_{P}}\left(w^{B Y}\right)^{\rho_{P} \sigma_{P}}\right] \frac{1}{\rho_{P}} y_{P}^{P P}
$$

and

$$
x_{P}^{B Y}=\left(\alpha_{P}^{B Y}\right)^{\sigma_{P}}\left(w^{B Y}\right)^{-\sigma_{P}} \gamma_{P}^{-1}\left[\left(\alpha_{P}^{R W}\right)^{\sigma_{P}}\left(w^{R W}\right)^{\rho_{P} \sigma_{P}}+\left(\alpha_{P}^{B Y}\right)^{\sigma_{P}}\left(w^{B Y}\right)^{\rho_{P} \sigma_{P}}\right]_{\rho_{P}}^{1} y_{P}^{P P}
$$

where $w^{R W}$ and $w^{B Y}$ are the input prices of roundwood and by-products respectively.

The profit function of the pulp and paper industry is written as:

$$
\pi_{P}=p^{P P} y_{P}^{P P}-\left(w^{R W} x_{P}^{R W}+w^{B Y} x_{P}^{B Y}\right)
$$

where $p^{P P}$ is the price of pulp.

\subsection{Empirical Specification of the Heating Industry}

The heating industry is assumed to use logging residues and by-products. The production function is specified as:

$$
\begin{gathered}
y_{H}^{H E}=\gamma_{H}\left[\alpha_{H}^{L G}\left(x_{H}^{L G}\right)^{-\rho_{H}}+\alpha_{H}^{B Y}\left(x_{H}^{B Y}\right)^{-\rho_{H}}\right]^{-1 / \rho_{H}} \\
x_{H}^{L G}=\left(\alpha_{H}^{L G}\right)^{\sigma_{H}}\left(w^{L G}\right)^{-\sigma_{H}} \gamma_{H}^{-1}\left[\left(\alpha_{H}^{L G}\right)^{\sigma_{H}}\left(w^{L G}\right)^{\rho_{H} \sigma_{H}}+\left(\alpha_{H}^{B Y}\right)^{\sigma_{H}}\left(w^{B Y}\right)^{\left.\rho_{H} \sigma_{H}\right] \frac{1}{\rho_{H}} y_{H}^{H E}}\right.
\end{gathered}
$$

where $y_{H}^{H E}$ is the output of heat, $x_{H}^{L G}$ and $x_{H}^{B Y}$ are the demanded inputs of logging residues and by-products. $\gamma_{H}$ is a scale parameter for the heating industry, $\alpha_{H}^{L G}$ and $\alpha_{H}^{B Y}$ (where $\left.\alpha_{H}^{B Y}=\left(1-\alpha_{H}^{L G}\right)\right)$ are distribution parameters for logging residues and by-products respectively. As in the case of the pulp and paper industry these parameters are calibrated using benchmark values. $\rho_{H}$ is the heating industry's specific $\rho$-value based on the elasticity of substitution $\left(\sigma_{H}\right)$ between the inputs. The heating industry's associated demand functions of logging residues and by-products are specified as:

and

$$
x_{H}^{B Y}=\left(\alpha_{H}^{B Y}\right)^{\sigma_{H}}\left(w^{B Y}\right)^{-\sigma_{H}} \gamma_{H}^{-1}\left[\left(\alpha_{H}^{L G}\right)^{\sigma_{H}}\left(w^{L G}\right)^{\rho_{H} \sigma_{H}}+\left(\alpha_{H}^{B Y}\right)^{\sigma_{H}}\left(w^{B Y}\right)^{\rho_{H} \sigma_{H}}\right] \frac{1}{\rho_{H}} y_{H}^{H E}
$$

where $w^{L G}$ and $w^{B Y}$ are the input prices of logging residues and by-products respectively.

The profit function of the heating industry is written as

$$
\pi_{H}=p^{H E} y_{H}^{H E}-\left(w^{L G} x_{H}^{L G}+w^{B Y} x_{H}^{B Y}\right)
$$

where $p^{H E}$ is the price of heat.

As the quantity of logging residues demanded by the heating industry only accounted for a small share of the total supplied quantity, a slack variable is included to account for the remaining quantity. $x_{E}^{L G}$ is the demanded quantity of logging residues by the other industries in the energy sector. Logging residues are also utilized in e.g., the combined power and heating industry and the refined woodfuel industry. The quantity demanded of logging residues by the other industries in the energy sector is assumed to be exogenously fixed.

It is assumed that all markets clears where the market clearing conditions are defined as:

$$
\begin{aligned}
& y_{F}^{R W}=x_{S}^{R W}+x_{P}^{R W} \\
& y_{F}^{L G}=x_{H}^{L G}+x_{E}^{L G} \\
& y_{S}^{B Y}=x_{P}^{B Y}+x_{H}^{B Y}
\end{aligned}
$$

The industries' objective is to maximize their profits. The optimal input combination is where the technical rate of substitution equals the input price ratio. The input decision by the industries is hence determined by the marginal product of the inputs and input prices. The model endogenously determines the prices and quantities for the included markets, given a constant exogenously determined output supply. The objective function of the model is defined as:

$$
\pi_{T O T}=\pi_{F}+\pi_{P}+\pi_{H}
$$

where $\pi_{T O T}$ is the sum of the profits of the forestry, the 
pulp and paper industry and the heating industry, respectively.

\section{Data, Parameters and Scenario Description}

\subsection{Data Sources}

The output and input volumes and prices are presented in Table 1. All observations are for year 2007. Output consumed internally by the included industries is not considered, i.e., only the net output production is considered. Data on the forestry's output of roundwood was obtained from FAOSTAT (2010). Following Lundmark (2007) the production of logging residues are approximated to be 15 percent of the harvested roundwood level. The output of by-products was calculated by adding the output levels of woodchips and sawdust produced by the sawmill industry and collected from SDC (2009). The output of sawn wood is obtained from SDC (2009) and the output of pulp from the Swedish Forest Agency (2009). The output of the heating industry is based on heat produced by forest fuel. The production of heat originating from by-products and logging residues is approximated using the average efficiency ( 87 percent) and the input levels. The required data was collected from Statistics Sweden (2009). Data on the sawmill industry's input of roundwood (timber) is collected from SDC (2009). The input of roundwood (pulpwood) and by-products to the pulp and paper industry is also obtained from SDC (2009). The input level of byproducts is calculated using the input levels of chips and sawdust. The heating industry's input of by-products and logging residues is collected from Statistics Sweden (2009).

The price of roundwood, by-products and logging residues was collected from the Swedish Forest Agency (2009). The price of roundwood is the weighted average price of timber and pulpwood. The price paid for byproducts differs between the forest industry and the energy sector, with the price paid by the forest industry generally being higher. The price presented here is a weighted average of the two. The price of sawn wood and pulp are export prices obtained from the Swedish Forest Agency (2009). The price of heat is collected from Statistics Sweden (2008).

Table 1. Output and input volumes and prices

\begin{tabular}{|c|c|c|c|}
\hline & $\begin{array}{l}\text { Output level } \\
\text { (million } \\
\text { m3s) }\end{array}$ & $\begin{array}{l}\text { Input level } \\
\text { (million } \\
\text { m3s) }\end{array}$ & $\begin{array}{l}\text { Price } \\
(\mathrm{SEK} / \mathrm{m3s})\end{array}$ \\
\hline \multicolumn{4}{|l|}{ Forestry } \\
\hline Roundwood & 72.30 & - & 335 \\
\hline Logging residues & 10.85 & - & 304 \\
\hline \multicolumn{4}{|l|}{ Sawmill } \\
\hline Roundwood & - & 38.19 & 335 \\
\hline By-products & 21.55 & - & 306 \\
\hline Sawn wood & 18.74 & - & 2354 \\
\hline \multicolumn{4}{|l|}{ Pulp and paper } \\
\hline Roundwood & - & 36.20 & - \\
\hline
\end{tabular}

\begin{tabular}{llll}
\hline & $\begin{array}{l}\text { Output level } \\
\text { (million } \\
\text { m3s) }\end{array}$ & $\begin{array}{l}\text { Input level } \\
\text { (million } \\
\text { m3s) }\end{array}$ & $\begin{array}{l}\text { Price } \\
\text { (SEK/m3s) }\end{array}$ \\
\hline $\begin{array}{l}\text { By-products } \\
\text { Pulp }\end{array}$ & - & 11.66 & 306 \\
Heating & $12.40 \mathrm{a}$ & & $4439 \mathrm{~b}$ \\
Logging residues & - & 0.04 & 304 \\
$\begin{array}{l}\text { By-products } \\
\text { Heat }\end{array}$ & - & 6.34 & 306 \\
$\begin{array}{l}\text { Other energy industries } \\
\text { Logging residues }\end{array}$ & $5.90 \mathrm{c}$ & - & 1357 \\
\hline
\end{tabular}

${ }^{a}$ Measured in (million) tonnes. ${ }^{b}$ Measured in SEK/tonnes. ${ }^{c}$ Converted from TWh to (million) $\mathrm{m}^{3} \mathrm{~s}$ using $1 \mathrm{TWh}=10^{6 *} 0.47 \mathrm{~m}^{3} \mathrm{~s}$.

Sources: FAOSTAT (2010); SDC (2009); Statistics Sweden (2008, 2009); Swedish Forest Agency (2009)

In addition, the harvesting costs and the annual growth rate of the forest are included in the model. The harvesting costs are the costs for thinning and cutting incurred by the forestry and set to 253 SEK per $\mathrm{m}^{3}$ (Swedish Forest Agency, 2009). The growth rate is the mean annual volume increment for all forest types and set to 101.6 million $\mathrm{m}^{3}$ (Swedish Forest Agency, 2009).

\subsection{Parametric Assumptions}

Generally, empirical estimates of substitution elasticities for forest products are difficult to obtain. It is commonly assumed that it is more difficult to substitute between forest products in the pulp and paper industry than in the heating industry. That is, the elasticities of substitution are generally assumed to be lower in the pulp and paper industry than in the heating industry. This assumption is confirmed by Olsson and Lundmark (2013), which estimates elasticities of substitution for forest products. The elasticity of substitution between roundwood and byproducts in the pulp and paper industry is estimated to 0.19 . The substitution elasticity between logging residues and by-products in the heating industry is estimated to 6.93 .

There are several econometric studies on the relationship between roundwood supply and price. For example, Toppinen and Kuuluvainen (1997) estimate the pulpwood price elasticity of supply to 0.41 in Finland (which has a similar market structure to Sweden). The price elasticity of pulpwood supply and timber supply is estimated to 0.23 and 0.5, respectively by Ankarhem et al., (1999) in Sweden. The same elasticities are estimated to 0.37 and 0.68 by SLU (2004). The elasticity of roundwood supply is set to 0.5 . The elasticity of supply for logging residues and by-products are assumed to be relatively more elastic and set to ten.

\subsection{Scenario Descriptions}

The baseline scenario is the norm to which the other scenarios are compared to and calibrated to the 2007 situation. Four scenarios with different development paths are considered. The policies implemented to achieve the 2degree target are assumed to result in an increase in the demand for forest products from the heating industry. In addition, different development paths for the industries are 
considered. An overview of the scenarios is given in Table 2.

Table 2. Development paths in the scenarios

\begin{tabular}{|c|c|c|c|c|}
\hline & $\begin{array}{l}\text { Heating } \\
\text { industry }\end{array}$ & $\begin{array}{c}\text { Pulp and } \\
\text { paper } \\
\text { industry }\end{array}$ & $\begin{array}{l}\text { Sawmill } \\
\text { industry }\end{array}$ & $\begin{array}{c}\text { Other } \\
\text { industries in } \\
\text { energy sector }\end{array}$ \\
\hline Scenario 1 & $\begin{array}{c}\text {----Outpu } \\
50 \% \\
\text { increase }\end{array}$ & vel------- & \multicolumn{2}{|c|}{---------Input level-------- } \\
\hline Scenario 2 & $\begin{array}{c}50 \% \\
\text { increase }\end{array}$ & $\begin{array}{c}20 \% \\
\text { increase }\end{array}$ & & \\
\hline Scenario 3 & $\begin{array}{c}50 \% \\
\text { increase }\end{array}$ & $\begin{array}{c}20 \% \\
\text { increase }\end{array}$ & $\begin{array}{c}20 \% \\
\text { decrease }\end{array}$ & \\
\hline Scenario 4 & $\begin{array}{c}50 \% \\
\text { increase }\end{array}$ & & & $50 \%$ increase \\
\hline
\end{tabular}

\section{Scenario Results and Implications}

Table 3present the results for the baseline scenario and for the four scenarios, reported as percentage changes compared to the baseline scenario. In the baseline scenario the forestry supplies 74.4 million $\mathrm{m} 3$ of roundwood and 7.4 million $\mathrm{m} 3$ of logging residues, while he sawmill industry supplies 18 million $\mathrm{m} 3$ of by-products. The pulp and paper industry consumes 36.2 million $\mathrm{m} 3$ of roundwood and 11.7 million $\mathrm{m} 3$ of by-products. The heating industry consumes 0.04 million $\mathrm{m} 3$ of logging residues and 6.3 million $\mathrm{m} 3$ of by-products. The prices are 335, 306 and 304 SEK per m3 for roundwood, logging residues and by-products, respectively.

In scenario 1 the heat production is assumed to increase by 50 percent. The results suggest that the heating industry's demand of by-products will increase by 50 percent and the demand for logging residues by 58.3 percent relative the baseline scenario. However, the increase in logging residues is from a low level thus the increase does only slightly affect the price. The price of byproducts increase by 0.8 percent inducing the pulp and paper industry to substitute by-products (decreases by 0.1 percent) in favor of roundwood (increases by 0.03 percent).In total, the heating industry's increase in the demand of by-products is larger than the decrease in demand by the pulp and paper industry. The sawmills increase of by-products by 8.1 percent imply that the maximum level is reached. Overall, the competition for byproducts may become relatively intense given an increase of 50 percent in the heat production. The pulp and paper industry's ability to substitute, at least small quantities, of by-products for roundwood may help reduce the price of by-products and the competition.

Scenario 2 combines an increase in heat production by 50 percent with an increase in the pulp production by the pulp and paper industry by 20 percent. The results indicate that demand for roundwood by the pulp and paper industry increases by 19.2 percent and the demand for by-products increases by 23.0 percent. The price of roundwood increases by 19.5 percent and the price of by-products by 0.8 percent. The heating industry increases their demand for logging residues by 58.3 percent while their demand for by-products decreases by 19.3 percent. The output of roundwood increases by 9.3 percent while the output of byproducts increases by 8.1 percent. The scenario was expected to result in an increase in the input demand of the heating and pulp and paper industries. While the pulp and paper industry increase their demand for its inputs, the heating industry decrease their demand for by-products. The reason behind this behavior is likely the limited supply of by-products. The price of by-products does however only increase slightly and the heating industry seems to decrease their by-product consumption in favor for logging residues. In addition, the relative price between by-products and logging residues is lower than between by-products and roundwood. This could be reasons why the competition seems to be relatively limited also in this case.

Table 3. Simulated output and input volumes and prices of forest products for baseline and policy scenarios

\begin{tabular}{|c|c|c|c|c|c|}
\hline Output level & Baseline & Scenario 1 & Scenario 2 & Scenario 3 & Scenario 4 \\
\hline Forestry & (million m3) & \multicolumn{4}{|c|}{$(\%)$} \\
\hline Roundwood & 74.4 & 0.01 & 9.3 & -0.5 & 0.01 \\
\hline Logging residues & 7.4 & 0.3 & 0.3 & 0.2 & 49.9 \\
\hline \multicolumn{6}{|l|}{ Sawmill } \\
\hline By-products & 18.0 & 8.1 & 8.1 & -13.5 & 8.1 \\
\hline \multicolumn{6}{|l|}{ Input level } \\
\hline \multicolumn{6}{|l|}{ Pulp and paper } \\
\hline Roundwood & 36.2 & 0.03 & 19.2 & 20.0 & 0.03 \\
\hline By-products & 11.7 & -0.1 & 23.0 & 20.1 & -0.1 \\
\hline \multicolumn{6}{|l|}{ Heating } \\
\hline Logging residues & 0.04 & 58.3 & 58.3 & 36.1 & 19.4 \\
\hline By-products & 6.3 & 50.0 & -19.3 & -75.3 & 23.2 \\
\hline Price & $(\mathrm{SEK} / \mathrm{m} 3)$ & & & & \\
\hline Roundwood & 335 & 0.03 & 19.5 & -1.1 & 0.03 \\
\hline Logging residues & 304 & 0.03 & 0.03 & 0.02 & 4.1 \\
\hline By-products & 306 & 0.8 & 0.8 & -1.4 & 0.8 \\
\hline Profit & (million SEK) & & & & \\
\hline Forestry & 6,100 & 0.1 & 96.6 & -5.0 & 0.1 \\
\hline Sawmill & 36,822 & 1.3 & -5.5 & 5.0 & 1.3 \\
\hline Pulp and paper & 39,358 & -0.1 & 12.7 & 20.6 & -0.1 \\
\hline Heating & 6,050 & 58.7 & 72.5 & 90.8 & 58.7 \\
\hline
\end{tabular}


Scenario 3 combines the assumptions of the two previous scenarios with a decrease in the demand for roundwood by the sawmill industry by 20 percent. Not surprisingly, the results show that the decrease in the demand for roundwood by sawmills will reduce their output of byproducts negatively by 13.5 percent. This output level is at the limit of the restriction set by sawmills' roundwood demand. The pulp and paper industry increase their demand of roundwood and by-products by 20.0 and 20.1 percent, respectively. The heating industry increase their input demand of logging residues but decrease their input demand of by-products by a relatively large amount. The increase in the pulp and paper industry's demand, in percentage terms, is larger for by-products than for roundwood, this is explained by the relatively larger fall in the price of by-products than in price of roundwood.

Finally, the results for scenario 4 indicate that the pulp and paper industry increases their demand of roundwood slightly ( 0.03 percent) and decrease their demand of byproducts slightly $(0.10$ percent $)$. The heat industry increases their demand of by-products by 50.2 percent and logging residues by 19.4 percent. The price of logging resides increases by 4.1 percent. Overall, the pulp and paper industry is relatively unaffected in this scenario. However, the logging residue price does increase suggesting an intensified competition for logging residues between the industries within the energy sector.

\subsection{Sensitivity Analysis}

As the elasticities of substitution are important parameters, these have been changed to test the robustness of the results. The elasticities of substitution for the pulp and paper industry and the heating industry are increased respectively decreased by 50 percent. The elasticity of substitution for the heating industry is thus set to 10.39 respectively 3.46 and for the pulp and paper industry it is set to 0.28 and 0.09 respectively. The results from the sensitivity check of input and output quantities and prices are reported in Table 4. The results from the sensitivity analysis indicate that the model is relatively robust.

Table 4. Percentage Change in Output and Input Quantities and Prices with a $\pm 50 \%$ Change in the Elasticity of Substitution

\begin{tabular}{|c|c|c|c|c|c|c|c|c|}
\hline \multirow{2}{*}{ Output level } & \multicolumn{2}{|c|}{ Scenario 1} & \multicolumn{2}{|c|}{ Scenario2 } & \multicolumn{2}{|c|}{ Scenario3 } & \multicolumn{2}{|c|}{ Scenario4 } \\
\hline & $+50 \%$ & $-50 \%$ & $+50 \%$ & $-50 \%$ & $+50 \%$ & $-50 \%$ & $+50 \%$ & $-50 \%$ \\
\hline Forestry & & & $-\cdots$ & ------ & ------- & ---- & & \\
\hline Roundwood & 0.01 & -0.01 & -0.17 & 0.18 & 0.00 & 0.00 & 0.01 & -0.01 \\
\hline $\begin{array}{l}\text { Logging residues } \\
\text { Sawmill }\end{array}$ & 0.01 & -0.03 & 0.01 & -0.03 & -0.04 & 0.03 & -0.04 & 0.04 \\
\hline $\begin{array}{l}\text { By-products } \\
\text { Input level } \\
\text { Pulp and paper }\end{array}$ & 0.00 & 0.00 & 0.00 & 0.00 & 0.00 & 0.00 & 0.00 & 0.00 \\
\hline Roundwood & 0.02 & -0.01 & -0.33 & 0.34 & -0.01 & 0.01 & 0.02 & -0.01 \\
\hline $\begin{array}{l}\text { By-products } \\
\text { Heating }\end{array}$ & -0.05 & 0.05 & 1.16 & -1.21 & 0.02 & -0.03 & -0.05 & 0.05 \\
\hline Logging residues & 1.75 & -3.51 & 1.75 & -3.51 & -6.12 & 4.08 & -9.30 & 11.63 \\
\hline $\begin{array}{l}\text { By-products } \\
\text { Price }\end{array}$ & -0.02 & 0.01 & -0.02 & 0.01 & -0.19 & 0.26 & 0.05 & -0.05 \\
\hline Roundwood & 0.01 & -0.02 & -0.35 & 0.36 & -0.01 & 0.01 & 0.01 & -0.02 \\
\hline Logging residues & 0.00 & 0.00 & 0.00 & 0.00 & 0.00 & 0.00 & 0.00 & 0.00 \\
\hline By-products & 0.00 & 0.00 & 0.00 & 0.00 & 0.00 & 0.00 & 0.00 & 0.00 \\
\hline
\end{tabular}

\section{Conclusions}

The energy sector has in the past decades increased its utilization of forest products. This is, to a large extent, caused by economic policies introduced to reduce the emission of greenhouse gases. Since the increasing utilization is believed to continue, it is of interest to analyze the affects it might have on the competition between the forest industries and the energy sector. Thus, the purpose is to analyze the extent and degree of the competition for forest products in the presence of climate and energy policies.

The results indicate that climate policies that would increases the utilization of forest products in the energy sector would have rather modest effects on the pulp and paper industry. The forest product prices would slightly increase and the pulp and paper industry would be able to alleviate this effect by substituting between different feed-stocks.

Climate policies could however affect the possibilities for the pulp and paper industry to expand its production. In such a situation both the heat industry and the pulp and paper industry will demand larger volumes of forest products compared to the current situation. The limited supply of by-products from sawmills suggests that the competition in this case would be relatively intense. The price of by-products does however only increase slightly and the heat industry seems to decrease their by-product consumption in favor for logging residues.

In the event of an expanding pulp and paper industry, simultaneously as sawmills experiences a fall in their production, the effects of a climate policy is rather unintuitive. Despite the lower supply and higher demand for by-products, the price does not increase. Instead the price decreases. Therefore, the competition does not 
intensify in this situation either.

An increase in the demand for forest products from other industries in the energy sector does seem to give rise to a more intense competition. That is, a climate policies that only affects the increase in the heating industry's utilization of forest products in combination with a policy that increases the rest of the energy sector's demand for forest products will result to a higher price of logging residues and increase the competition.

In summary, the results do not indicate an intensified competition between the forest industries and the energy sector. An increase in the competition between industries in the energy sector can however be observed.

\section{Acknowledgement}

Financial support from the LETS research program and its financiers: the Swedish Environmental Protection Agency, the Swedish Energy Agency, the Swedish Transport Administration, and Vinnova are gratefully acknowledged. We also thank Bio4Energy, a strategic research environment appointed by the Swedish government, for supporting this work.

\section{Appendix}

Table A1. List of indices, parameters and variables.

\begin{tabular}{|c|c|}
\hline Indices & \\
\hline $\mathrm{i}$ & industry $(\mathrm{i}=\mathrm{F}, \mathrm{S}, \mathrm{P}, \mathrm{H})$ \\
\hline j & input $(j=R W, B Y, L G)$ \\
\hline f & output (f= RW, BY, LG, SW, PP, HE) \\
\hline \multicolumn{2}{|l|}{ Parameters } \\
\hline$\gamma_{i}$ & scale parameter of industry $i$ \\
\hline$\alpha_{i}^{j}$ & distribution parameter of industry $i$ for input $j$ \\
\hline$\rho_{i}=\frac{1}{1-\sigma_{i}}$ & function of the elasticity of substitution of industry $i$ \\
\hline$\sigma_{i}$ & elasticity of substitution in industry $i$ \\
\hline$\beta^{j}$ & $\begin{array}{l}\text { exogenous cost component in input prices independent } \\
\text { of harvesting levels }\end{array}$ \\
\hline$\delta^{j}$ & $\begin{array}{l}\text { shift parameter accounting for factors other than price } \\
\text { affecting the supply of input } j\end{array}$ \\
\hline$\phi^{j}$ & elasticity of supply for input $\mathrm{j}$ \\
\hline$k^{j}$ & $\begin{array}{l}\text { capacity restriction (maximum production level) for } \\
\text { input } j\end{array}$ \\
\hline$\tau_{F C O S T}$ & $\begin{array}{l}\text { annual logging cost per cubic meter harvested } \\
\text { roundwood }\end{array}$ \\
\hline$\psi_{F G R O W T H}$ & annual growth rate of the forest \\
\hline \multicolumn{2}{|l|}{ Variables } \\
\hline$y_{i}^{f}$ & output of f of industry $i$ \\
\hline$x_{i}^{j}$ & demand of industry $i$ for input $j$ \\
\hline$w^{j}$ & price of input $j$ \\
\hline$p^{f}$ & price of output $\mathrm{f}$ \\
\hline$\pi_{i}$ & profit of industry $i$ \\
\hline$\pi_{T O T}$ & sum of the profits of all industries \\
\hline
\end{tabular}

\section{References}

[1] Ankarhem, M., R. Brännlund and M. Sjöström.(1999). Biofuels and the forest sector. In Yoshimoto, A. and K. Yukutake (eds.). Global concerns for forest resource utilization; sustainable use and management. Kluwer Academic Publishers, Dordrecht.

[2] Bolkesjo T.F., E. Trømberg and B. Solberg. (2006). Bioenergy from the forest sector: Economic potential and interactions with timber and forest products markets in Norway. Scandinavian Journal of Forest Research, 21(2): 175-185.

[3] Buongiorno, J., S. Zhu, D. Zhang J. Turner and D. Tomberlin. (2003). The global forest products model: Structure, estimation and applications. Academic Press, Elsevier Sci., New York, USA.

[4] Brännlund, R., R. Lundmark and P. Söderholm. (2010). Kampen om skogen - Koka, såga, bränna eller bevara? SNS Förlag, Stockholm, Sweden.

[5] Böhringer, C., T.F. Rutherford and W. Wiegard. (2003). Computable general equilibrium analysis: Opening a black box. ZEW Discussion Paper 03-56, Mannheim, Germany.

[6] European Union (EU). (2009). Directive 2009/28/EC of the European Parliament and Council. Official Journal of the European Union, 140:16-62.

[7] FAO - Food and agriculture organization of the United Nation. (2010). FAOSTAT Forestry (www.fao.org)

[8] Hammarlund, C., K. Ericsson, H. Johansson, R. Lundmark, A. Olsson, E. Pavlovskaia and F. Wilhelmsson. (2010). Bränsle för ett bättre klimat. Rapport 2010:5, AgriFood. Lund, Sweden.

[9] Haynes, R.W. (1993). Forestry sector analysis for developing countries: Issues and methods. PNW-GTR-314. USDA, Forestry Service, Pacific Northwest Research Station, Portland, USA.

[10] Kallio, M., D.P. Dykstra and C.S. Binkley.(1987). The global forest sector: An analytical perspective. Wiley, New York, USA.

[11] Kallio, M., A. Moiseyev, and B. Solberg, (2004). The global forest sector model EFI-GTM - The model structure. Internal report No.15. European Forest Institute, Finland.

[12] Lundmark, R.(2007). Dependencies between forest products sectors: a partial equilibrium analysis. Forest Products Journal, vol. 57(9): 79-86.

[13] Lundmark, R and P. Söderholm. (2004). Brännhett om svensk skog. SNS Förlag, Stockholm, Sweden.

[14] Olsson, A. and R. Lundmark.(2011). Factor substitution and procurement competition for forest resources in Sweden. Economics Unit, Luleå University of Technology.

[15] Mansikkasalo, A. (2007). The European forest trade model EU policy and the impact on forest raw material use. Licentiate Thesis Economics Unit, Luleå University of Technology.

[16] SDC. (2009). Skogsindustrins virkesförbrukning samt produktion av skogsprodukter 2004-2008. Uppsala, Sweden. 
[17] SLU. (2004). SLU:s bioenergiutredning. The Swedish University of Agricultural Sciences, Uppsala, Sweden.

[18] Statistics Sweden. (2008). Energy prices and electricity suppliers switching, 4th Quarter 2007. EN 24 SM 0801, Örebro, Sweden.

[19] Statistics Sweden .(2009). Electricity supply, district heating and supply of natural and gasworks gas 2007. EN 11 SM 0901, Orebro, Sweden.

[20] Swedish Forest Agency.(2009). Swedish Statistical Yearbook of Forestry 2009. Jönköping, Sweden.

[21] Toppinen, A. and J. Kuuluvainen.(1997). Structural changes in sawlog and pulpwood markets in Finland. Scandinavian Journal of Forest Research, 12(4): 382-389.
[22] Trømberg E. and B. Solberg. (2010). Forest sector impacts of the increased use of wood in energy production in Norway. Forest Policy and Economics, 12(1):39-47.

[23] United Nations (UN). (2007). United Nations Forum on Forests - Report of the seventh session. E/2007/42.

[24] United Nations Programme to Reduce Emissions from Deforestation and Degradation (UN-REDD) (2010). (www.un-redd.org).

[25] Varian, H.R. (1992). Microeconomic Analysis (3rd ed). Norton \& Company, USA.

[26] Åkerman, J., K. Isaksson, J. Johansson and L. Hedberg. (2007). Tvågradersmålet i sikte? Scenarier för det svenska energi- och transportsystemet till år 2050. Rapport 5754, Naturvårdsverket. Stockholm, Sweden. 